\title{
Hazard Management in Tourism: A Case Study of The Senaru-Sembalun Hiking Trail, Mount Rinjani National Park, Indonesia
}

\author{
E. K. S. Harini Muntasib*, Fitri Nadhira, Resti Meilani
}

Department of Forest Resource Conservation and Ecotourism, Faculty of Forestry, IPB University (Bogor Agricultural University), Dramaga Campus, Bogor, Indonesia 16680

Received October 16, 2019/Accepted December 6, 2019

\begin{abstract}
Mount Rinjani (3726 masl) is the second-highest volcano in Indonesia with a newer active volcano called Mount Barujari (2376 masl) inside its crater. The mountain has become the center of tourist destinations in West Nusa Tenggara Province, with hiking as the most popular activity carried out by visitors. This study aimed to identify physical and biological hazard potentials and activities that may put visitors at risk to prepare hazard management recommendations. We carried out an interview and field observation for the study in April 2018. We used the United Nations Environment Programme (UNEP) risk assessment as a reference in biological and physical hazard analysis, and the National Patient Safety Agency for human activities. We also used ArcGIS 10.1 software to develop a map of hazard potentials. Cliff (physical hazard), tree roots (biological hazard), and running (activity) were hazards with the highest risks. All four management options offered by the UNEP, i.e., reducing risk, accepting the tolerable risk, avoiding risk, and transferring risk, were applicable in this area. We proposed that the management considering to increase local community and visitors' knowledge of hazards as a preventive measure while continuing to provide repressive measures.
\end{abstract}

Keywords: hazard management, hiking trails, Rinjani National Park, risk reduction measures, tourism

*Corresponding author, email: harinimuntasib@yahoo.com

\section{Introduction}

Hazard is something with damaging potentials. The UNISDR (2015) defined hazard as "a potentially damaging physical event, phenomenon or human activity that may cause the loss of life or injury, property damage, social and economic disruption or environmental degradation." Hazard may come from a different source, i.e., natural, technological, social, and intentional hazards (UNISDR, 2004; Alexander, 2013), and it is a contributing factor to risk (Gupta, 2013). While hazard is an "existing situation" (Gupta, 2013) or source, the risk is the probability of 'harmful consequences' or predictable loses resulted from the combination of hazard and vulnerability of the community (UNISDR, 2004; Kumpulainen, 2006).

In tourism, hazard affects not only the visitors or tourists involved in the accident but also the image of the destination and the management itself. Accidents may leave an unpleasant memory that brings in bad images in the visitors' minds. Since recollection of memories may influence visitors in making a choice (Pigram, 1983), a bad impression of an accident may prevent visitors from coming back to the area where the accident happened. Suharto (2016) argues that there was a significant correlation between the image of a tourism destination and visitors' safety and security. $\mathrm{He}$ further suggests that the image influence visitors' motivation to visit the destination (Suharto, 2016).

Satisfaction also plays an important role in ensuring a return visit. It is "a strong indicator of loyalty" (Adinegara et al., 2017). Higher satisfaction would lead to a higher intention of return visit (Kwon \& Park, 2002). A study by (Aliman et al., 2016) also showed that destination image has a significant influence on visitors' satisfaction. Considering that safety may affect the destination image, it may also affect visitors' satisfaction toward a destination. Safety facility is among the factors that influence the intention of return visit (Kwon \& Park, 2002). It is not the sole factor, but it is an important factor in tourism (Jubenville et al., 1987). If visitors' motivation or their intention to re-visit a destination is decreasing, this would eventually result in a decreasing number of visits. For destination management, this will also lead to financial consequences, a decrease in the income generated from the visits.

Aside from the financial consequences, destination managers must ensure their visitors' safety. Ensuring visitors' safety means managing the hazards found in the area. Hazard 
management requires the identification of hazards, hazard assessment, and development of management plans (Jubenville et al. 1987; UNEP, 2008; Wilks \& Moore 2004). Therefore, a study of hazard management was carried out in Mount Rinjani, a popular tourism destination in Indonesia visited by thousands of tourists each year.

\section{Methods}

Location We carried out the study in April 2018 in the Sembalun-Senaru hiking trail of Mount Rinjani National Park. The mountain is situated in Lombok District, Nusa Tenggara Barat Province, Indonesia. The peak rises to an altitude of $3726 \mathrm{~m}$ above sea level, which puts the mountain as the highest mountain in the Lesser Sunda Islands, and as the second-highest volcano in Indonesia. The Mount Rinjani National Park Office managed the area that has been well known as the center of the tourist destination of Nusa Tenggara Barat Province. The scenic beauty found along its hiking trail has become an attraction for the visitors, while the peak has become the ultimate destination for most of the visitors of the mountain. The number of visitors involved in hiking activity keeps increasing each year, and the Sembalun-Senaru hiking trail is the most popular trail visited by a very high number of visitors.

Data collection Data on the types of physical, biological, and human activity hazards and the location of hazards were collected through interviews, field observation, and literature study. The interview involved:

(1) management officers responsible for tourism management in the area,

(2) community: community leader, community member who frequently hiked Mount Rinjani and/or involved in tourism management of Mount Rinjani, and

(3) visitors. There were a total of 60 respondents, each 30 for visitors and community members, interviewed in this study.

Data analysis We analyzed the physical and biological hazards in reference to risk assessment guidelines by classifying the hazard found based on the likelihood/probability and severity of consequences and then evaluating the risk using the risk evaluation matrix (Wilks \& Moore, 2004; UNEP, 2008). For human activity, we used Job Safety Analysis (JSA) or also known as Job Hazard Analysis (OSHA, 2002), and referred to NHS Risk Assessment (NPSA, 2008) in the classification and scoring of hazard.

We used data of past occurrences to determine the score probability/likelihood and the severity of the consequences for each hazard potential found in the location. The risk of each hazard potentials was calculated by multiplying score of likelihood and severity and used in determining the priority of risk prevention and control. In addition to risk assessment, we also carried out a spatial analysis to generate the map of hazard potentials using the ArcGIS 10.1. There were four risk reduction management options offered for tourism managers, i.e., reducing risk, avoiding risk, accepting the risk, and transferring risk (Wilks \& Moore, 2004; UNEP, 2008), and the management action recommendation was proposed in accordance with the management option.

\section{Results and Discussion}

Hiking tourism in Mount Rinjani Hiking was the most popular tourism activities for tourists with special interests. In Mount Rinjani, there were four official starting points/gates of the hiking trail, i.e., Senaru, Sembalun, Timbanuh, and Aiq Berik. Senaru and Sembalun were the most popular hiking trail. Visitors could take a return trip through the same trail and gate, or traverse to other gates, e.g., from Sembalun to Senaru. Hiking trail from Sembalun to the peak of Rinjani stretches along $14 \mathrm{~km}$, which takes approximately 11 hours of hiking through 3 posts and Pelawangan Sembalun. From Senaru, there was a $20 \mathrm{~km}$ distance from the gate to the peak that took roughly 14 hours through 3 posts, Pelawangan Senaru, Segara Anak Lake, and Pelawangan Sembalun.

Physical hazard potentials MRNP (Mount Rinjani National Park) area had diverse physical conditions, from relatively level area to mountain peak with a very steep slope. Hazard potentials found along the trail included gorge, steep and slippery trail, low temperature, fog, landslide, volcanic activity, and fire (Figure 1; Table 1).

Gorge In five years between 2013 and 2017, there had been ten accidents in Mount Rinjani due to the gorge. The accidents caused fractures on seven hikers and the death of three hikers who fell off to the gorge. The steep gorge, hikers' carelessness, and lack of safety facilities might have caused these accidents to occur. The occurrence data showed that the gorge posed a high-risk level. However, visitors and community both perceived the hazard as having a moderate risk level. There were also some cases where gorge had brought the dire risk of death to visitors in several tourism destinations in the world (Palmer, 2002), which confirmed the hazard of the gorge.

Slippery and steep trail The slippery and steep trail could be found in most of the hiking trail of Sembalun-Senaru. Rainfall increased the hazard of the trail. High rainfall causes increased mud volume. Hikers might easily slip and fall, injuring themselves in the process. Until April 2018, there had been 41 hikers who fell and sprained their limbs in these trails. During this month, rainfall in the Nusa Tenggara region ranges from 50-100 mm. Unlike in Mount Everest, where Sherpa/mountain guide plays a role in taking practical measures to prevent hikers from falling (Bjønness, 1986), safety measures, or facilities, such as fence or guardrail, were insufficient in Mount Rinjani. The condition put to the hazard of the trail at moderate risk. However, both visitors and the community perceived the hazard as having low risk.

Low temperature Hypothermia is a condition where body temperature is below 350C. One's resistance to low temperatures depends on their physical condition. Mount Rinjani was located on high altitude and surrounded by hills, making the temperature low. Prolonged exposure to low temperatures without sufficient protective clothing may cause hypothermia (CDC, 2005). During the 2013-2017, two hikers who experienced hypothermia had been successfully evacuated by the field officers of the mountain management. For this case, both visitors and the 


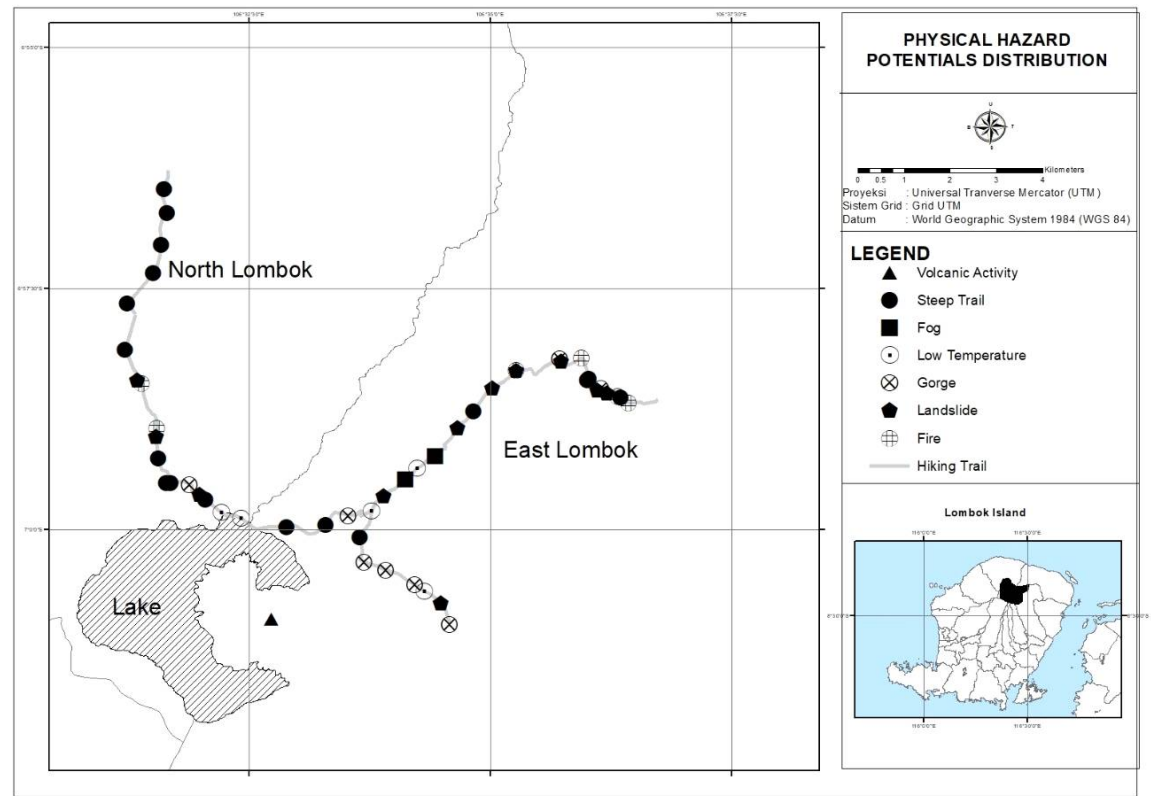

Figure 1 Map of physical hazard potentials distribution.

Table 1 Hazard potential and accident occurrence in Sembalun-Senaru Hiking Trail of Mount Rinjani

\begin{tabular}{lcll}
\hline Hazard potentials & $\begin{array}{c}\text { Number of } \\
\text { accidents }\end{array}$ & \multicolumn{1}{c}{ Year of occurrence } & $\begin{array}{c}\text { Consequences (numbers } \\
\text { indicating persons) }\end{array}$ \\
\hline Gorge & 10 & $2013,2014,2015,2017$ & 6 broken limbs; 4 sprained \\
Slippery/steep trail & 41 & $2013,2014,2015,2016,2017$ & 41 sprained legs \\
Low Temperature & 4 & $2015,2016,2017$ & 4 weak body \\
Fog & 2 & 2017 & 2 lost \\
Landslide & 0 & & 0 \\
Volcanic activity & 0 & & 0 \\
Fire & 0 & $2013,2014,2016,2017$ & 9 \\
Tree root & 9 & 2017 & 3 sprained legs \\
Long-tailed macaque & 3 & 2017 & 1 stinged \\
Bee/wasp & 1 & 2017 & 2 open wound \\
Transverse tree branch & 2 & & 0 \\
Wild boar & 0 & 2016,2017 & 0 \\
Eastern poison ivy & 0 & 4 drowned \\
Swimming & 4 & & \\
\hline
\end{tabular}

communitys' perception of the level of risk generated by low temperature were consistent with the occurrence data, i.e., low-risk level.

Fog Fog, which rises almost every morning and afternoon in the Mount Rinjani area, limited hikers' vision. Low temperature below dew point causes the formation of fog (Helicon, 2018). Based on BMKG observations throughout Indonesia from 1 to July 5, 2018, temperatures of less than 15 degrees Celsius were recorded in several areas that were entirely located in the highlands or at the foot of mountains such as Ruteng (NTT), Wamena (Papua), and Tretes (Pasuruan). The lowest temperature was recorded in Ruteng (NTT) with a value of 12 degrees Celsius on July 4, 2018. The poor visibility during fog occurrence may cause hikers to trip, fall, hit, or go astray. During 2013 - 2017, two hikers got lost due to fog limiting their vision. The hazard potential of fog had low risk, which is also consistent with the perception of visitors and community about the risk. 
Landslide The landslide had occurred on several locations along the hiking trail. However, the occurrences were not officially recorded. The landslide that occurred on Mount Rinjani was caused by an earthquake and the eruption of Mount Barujari in the middle of the Rinjani crater. Soil structure in the form of sand increases the number of landslides in the area. Many of these events occurred in August after the earthquake on Lombok Island. Based on reports from the management, landslides have occurred at several locations in the hiking trail. However, data about the landslide incident was never officially recorded by officers. That is because the landslide occurred when the hiking trail was closed, so there were never any casualties due to this potential danger. The consequence of the landslide is the disruption in the path when the ascent has been reopened. There had been no casualty or injury caused by landslide since it happened during the closing of a hiking trail. However, a landslide disrupted the trail, which brings about discomfort for the hikers. Since there had never been any accidents caused by landslide, the risk to hikers was low, and both the visitors and the community had the same perception of this.

Volcanic activities Mount Rinjani had a new active mountain, the Mount Barujari. Mount Barujari had erupted 12 times since 1846 to 2016 , each in $1846,1884,1901,1906$, 1909, 1915, 1944, 1966, 1994, 2004, 2009 dan 2016 (PVMBG, 2014). Volcanic activities of Mount Barujari did not significantly affect the surrounding community since the center of the eruption was located inside caldera that the lava and volcanic ashes flow from the eruption did not reach the community. Both visitors and the community perceived volcanic activities as having low risk, and the occurrence data were consistent with the perception.

Fire The fire had occurred five times in the hiking trail, either caused by the weather or fire that was lit recklessly by visitors or porter/guide. Based on records of accidents that have occurred in the Sembalun and Senaru climbing routes in 2013-2017. The management of Mount Rinjani National Park concluded that the weather mostly caused the occurrences of fire in Mount Rinjani since the fire occurred during the closing of the hiking trail. This condition differs from other places, such as in the United States, where most fires were caused by humans (Balch et al., 2017). Fire in Mount Rinjani had never caused death and therefore categorized as a low-risk hazard. Both visitors and the community also perceived fire as having low risk.

Biological hazard potentials Plants and animals may also present hazard for hikers of Mount Rinjani. These biological hazard potentials found in the hiking trail included tree root, long-tailed macaque, wasp and bee, transverse tree branch, wild boar, and eastern poison ivy/jelateng (Table 1; Figure 2).

Tree root Protruding tree root may present hazard potential for visitors who are not careful when climbing down through

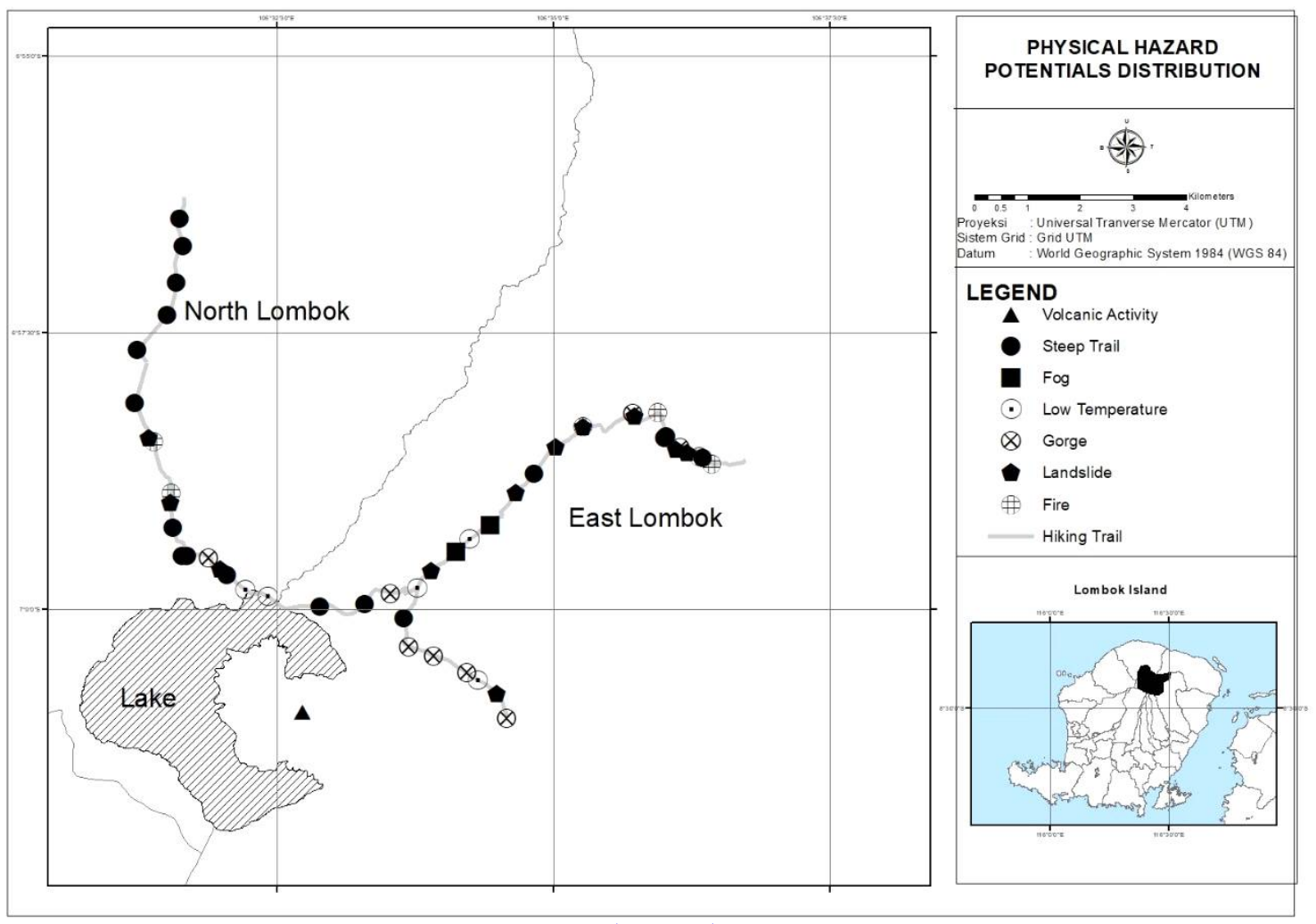

Figure 2 Map of biological hazard potentials distribution. 
Senaru trail. Hikers may trip over a tree root and cause them to fall or sprained their limbs (Gitapala, 2014). Protruding tree root (from Casuarina, Junglandaceae, and Rosaceae trees) could be found in a large number on the Senaru trail starting from Pos III to the Senaru Gate. During 2013-2017, there had been ten accidents caused by tree roots. Lack of safety facilities might also contribute to accidents. Hikers with visual aids (eyeglasses) were more susceptible to these hazards. The risk assessment showed that tree root presented moderate risk toward visitors. However, both visitors and the community perceived the hazard as having low risk.

Long-tailed macaque (Macaca fasicularis) Long-tailed macaque could be found in several locations, such as Pelawangan Senaru, Pelawangan Sembalun, and around Segara Anak Lake. Long-tailed macaque is aggressive in obtaining its food (Saputra et al., 2014; Pradhany et al., 2016). Heriyanto and Mukhtar (2011) stated that long-tailed macaque aggression usually occurred during daylight. In addition to the risk of losing food due to macaque aggression, Mardiah et al. (2015) alerted that contact between macaque and visitors may induce pathogen transmission from macaque to visitors, mainly when the macaque bites the visitors. However, there had not been any occurrence of macaque biting visitors in the Sembalun-Senaru hiking trail, and therefore the risk of macaque was low. Both visitors and the community also perceived macaque hazards as having low risk.

Wasp and bee Wasp and bee could be found in several locations along the Sembalun trail and also around Segara Anak Lake. Wasp and bee sting usually cause swelling or inflammation in the stung area (Golden, 2003). However, it may cause anaphylaxis, a heavier and severe consequence, on certain people with allergic hypersensitivity (Golden, 2003; Arnold \& Williams, 2011). However, it occurred to a small number of people, about 1 percent of children and 3 percent of adults (Golden, 2003). There had never been any occurrences of life-threatening allergic reaction from wasp and bee stings on hikers in Mount Rinjani, and therefore the risk of wasp and bee was low. The assessment was in line with both visitors and community perception of the hazard's risk.

Transverse tree branch A tree branch that is crossing the trail may also pose a risk to hikers who are not careful and pay less attention to the trail. A tree branch that crosses the trail was found on the hiking trail from Segara Anak Lake to Pelawangan Senaru. It is dangerous since the branch transverse on a narrow path with a steep slope, and there were not any safety facilities found in the area. Should the hikers less careful in crossing the branch, they may bump or trip and fall. However, there had never been any accidents recorded that were caused by the transverse branch, and therefore the risk was categorized as low. Both visitors and the community also identify the hazard as presenting low risk.

Wild boar (Sus scrofa) Wild boar could be found around Segara Anak Lake. The boar disturbed hikers when they tried to find food from hikers' camp at night, making a mess around the tent and even damaging the tent. A study by Heriyanto and Mukhtar (2011) confirmed that the animal attack at night.
The accident caused by wild boar had never happened in Mount Rinjani. However, it may occur if the hikers do not pay attention to their surrounding area. The hazard poses low risk, consistent with hikers and community perception of the hazard.

Eastern poison-ivy/Jelateng (Toxicodendron radicans) Eastern poison ivy, known by the locals as Jelateng, had the potential of harming the hikers. Contact of exposed skin with the leaf or other parts of poison ivy may hurt and sting and cause burning and itchy feeling from several hours to several days after the exposure (Schwartz, 1941; Darlington, 1986; Leland, 2010). The plants could be found near the Segara Anak Lake. There had never been any accidents caused by eastern poison ivy; however, there is still a probability of occurrence. The risk of poison ivy was considered low, both from the data of occurrence and the perception of visitors and the community.

Potentially hazardous human activities Potentially hazardous human activities were observed from the hikers and the community carrying out activities in the trail. The trail was divided into 11 segments based on posts, shelter, and tourism objects around the hiking trail (Figure 3). Hazard may be caused by an action or wrong decision made before or during hiking (Gitapala, 2014). There were five activities considered hazardous, i.e., running, bringing excessive burden, swimming, insufficient or lack of equipment, and fishing. The hazard presented moderate to critical risk (Table 2).

Running During hiking, a hiker usually has to bring backpack loaded with equipment and supplies. Carrying the backpack in uphill or downhill walking requires balance. Hikers have to keep their balance throughout the course. Otherwise, they will quickly get tired and may fall. Hikers can keep their balance by taking small steps, regulates their breathing, and do not force themselves to take long steps (Kurniawan, 2004). However, some hikers did not heed their safety by running on the trail. Running on a steep and slippery trail or a trail covered with tree roots is not a good idea, since it may cause accidents. Accidents due to running on the trail of Sembalun and Senaru had frequently occurred, particularly on trail segment IV, V, VI, VIII, IX, X, and XI. Segment IV and VI were dominated by slippery and steep trail, which present a high probability of accident occurrence for hikers who run. There was gorge along segment $\mathrm{V}$, while segment VIII, IX, X, and XI were covered by tree root in addition to the slippery and steep track.

Despite accident occurrence, somehow, people still perceived running in the trail will not cause accidents. There were running competition event held in the trail since 2016, called Rinjani 100. A large number of participants from various countries joined the event. In 2018, the participant of this event reached 1163 runners from 39 countries, showing an increase from the previous event. The event might have convinced many people that running is not hazardous, while it is the contrary. Running uphill and downhill requires skills that hikers may not have. Vernillo et al. (2017, p. 615) suggested that there were "changes in foot strike pattern and ground reaction forces, joint kinematics and kinetics, and 


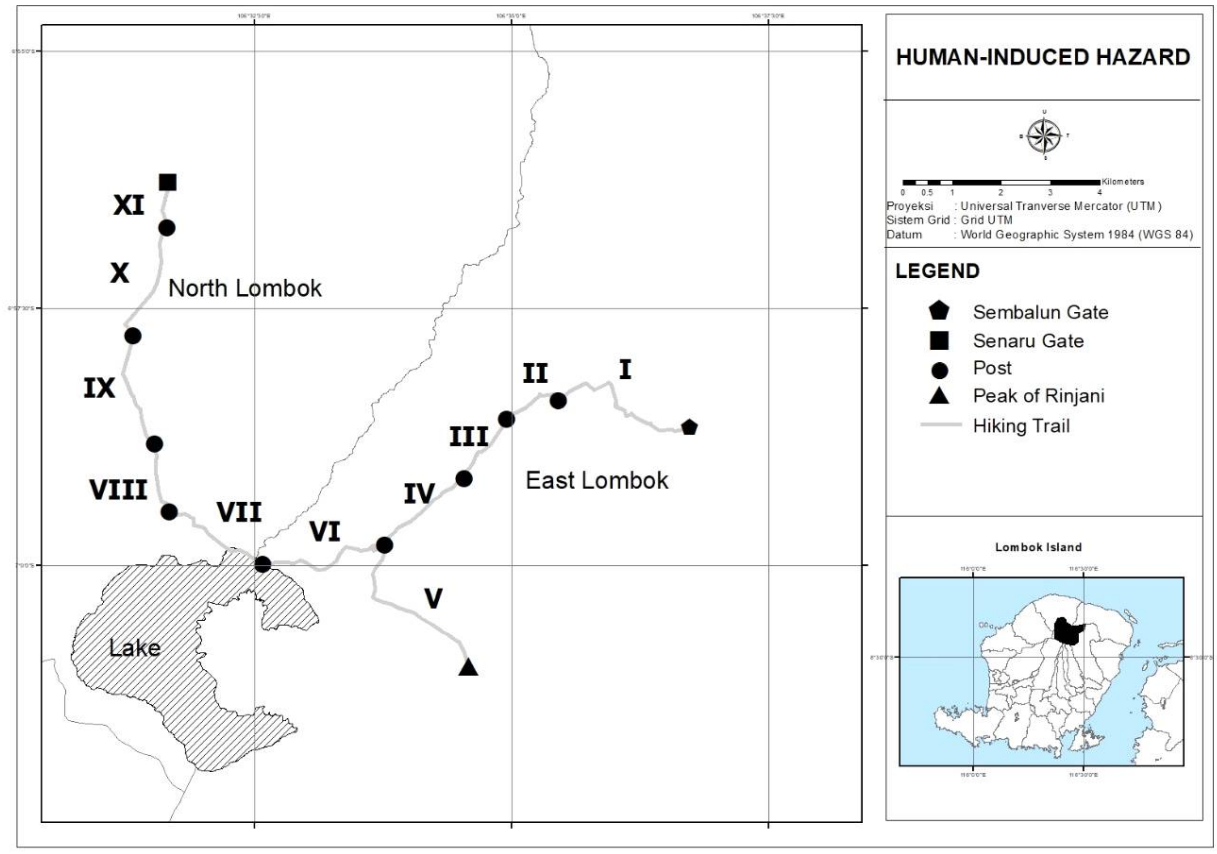

Figure 3 Map of human-induced hazards.

Table 2 Management action for hazard from human activity

\begin{tabular}{llll}
\hline Human Activity & Risk Level & Control Measures & $\begin{array}{l}\text { Risk after Control } \\
\text { Measures }\end{array}$ \\
\hline Downhill running & Critical & Education, such as warning board & Serious \\
& Score: 16 & $\begin{array}{l}\text { installation } \\
\text { Regulation/procedures enforcement, } 12\end{array}$ & Serious \\
Excessive burden/load & Critical & Skor: 12 \\
& Score: 16 & checking equipments & Serious \\
Swimming in Segara Anak & Critical & Education, such as warning board & Skor: 12 \\
Lake/Aiq Kalaq spring & Score: 10 & installation & Moderate \\
Insufficient hiking equipment & Serious & Regulation/procedures enforcement, & Skor: 8 \\
& Score: 6 & checking equipments & Minor \\
Fishing in Segara Anak Lake & Moderate & Education, such as warning board & Skor: 2 \\
& Score: 3 & installation & \\
\hline
\end{tabular}

impact-shock" as an adaptation that occurs in uphill and downhill running.

Bringing excessive burden Bringing excessive burden during a hike on the steep trail has the potential to cause an accident. Practical and effective supply loads are highly recommended. The total load for an individual should not exceed one third (Kurniawan, 2004) or 30\% (KwakHefferan, 2007) of the individual's body weight. People will get tired more easily when they carry an excessive burden, and the burden may also cause imbalance. In 2017, there was an accident involving a porter who brings supply exceeding the proper capacity. The management had issued a regulation on the maximum allowable burden for a porter to carry in hiking, i.e., $25 \mathrm{~kg}$. However, it was still far from effective implementation since checking for the load before hiking was out of questions due to a limited number of officers and a high number of hikers going in the area. Segment VI, VII, VIII, IX, X, and XI were the most hazardous part of the trail for hikers and/or porter who bring the excessive load. The segments were slippery and steep, presenting the hazard of falling, which put individuals in the risk of injury, broken bones, and even death.

Swimming Hikers sometimes spent their time swimming in Segara Anak Lake and Pemandian Aiq Kalaq. Water has both a positive and negative effect on the body (Sukthana et al., 2005). The hot water had been used for bathing and health purpose for many years (Sukthana et al., 2005; Erfurt, 2011), such as lowering blood pressure and relieving pain (Sukthana et al., 2005). However, swimming when someone was tired from exerting too much energy during hiking may potentially be dangerous for them. Water temperature affects the human body upon immersion in the water, and increased body temperature (Sukthana et al., 2005), hyperventilation, and general respiratory system discomfort were observed on immersion into the water with high temperature. The person may experience fatigue, dizziness, nausea, and losing 
consciousness (Healthline Editorial \& Jewell, 2017), and when to happen in the water may cause drowning and death. Four cases of hikers drowned and dead in the bathing sites of Mount Rinjani Hiking Trail had been recorded during 2013 2017. The most recent was in 2016, while none was recorded in 2017. Based on the record, the site with the potential hazard was located in segment VI and VII.

Insufficient or lack of hiking equipment Adequate physical preparation and hiking equipment are required to ensure the safety of the hikers, particularly in challenging environments such as the hiking trail in Mount Rinjani. The higher altitude, the thinnest oxygen available for breathing (Sukarmin, 1995), the colder the temperature, and therefore the condition may affect hikers' physical and mental health. Hikers should use adequate personal protective equipment to reduce the risk of hazard (Soputan et al., 2014; Naude, n.d.). There was a substantial contribution of the equipments to the risk (Sumann et al., 2015). Mountain shoes, warm clothing, gloves, hat, gaiters, sunglasses, and jackets are needed for hiking in Mount Rinjani. Interview and field observation found that hikers who were more prone to accidents were those who did not wear sufficient equipment. In 2016, there was a case of hypothermia, a condition when body temperature dropped below its normal temperature, occurred to a hiker in Segment $\mathrm{V}$ due to insufficient equipment. Risk of hypothermia increase in low temperature and strong wind occurrences (Kurniawan, 2004; Sumann et al., 2015). Wet clothing increases the risk further since it may cause a rapid drop in body temperature (Kurniawan, 2004).

Fishing Hikers often involved themselves in fishing activity in Segara Anak Lake. Data from the management of Mount Rinjani National Park showed no record of accidents due to fishing activity. However, considering the condition around the lake, there were accidents possibility if the hikers who do fishing do not pay attention to their surroundings. Hikers should stay vigil and be sensitive to the threat of hazards that may come anytime from the environment (Gitapala, 2014). Sites with fishing hazard potentials were located on segments VI and VII, around Segara Anak Lake. Though the land around the lake was only a bit sloping, since it was slippery, hikers may slip and fall into the lake (Wardana et al., 2015).

Existing hazard management in hiking tourism of Mount Rinjani The Mount Rinjani National Park Office, as the manager of the area, cooperated with the Regional Disaster Management Agency (BPBD) of NTB Province, National SAR Agency (BASARNAS) and Sembalun Community Health Center for handling accidents on hikers. The management also cooperated with the Center for Volcanology and Geological Disaster Mitigation (PVMBG) in carrying out visual and instrumental observation on Mount Rinjani from the Volcano Observation Post located in Sembalun Lawang Village. Other parties involved in hazard management of Mount Rinjani hiking trails included community groups such as Forum Porter dan Guide Sembalun (Sembalun Porter and Guide Forum), Forum Citra Wisata Rinjani (Rinjani Tourism Image Forum), Koperasi Jasa Wisata Alam Rinjani (Rinjani Nature-based Tourism
Services Cooperation), Kelompok Pemerhati Lingkungan Hidup/KPLH (Environmental Interest Group) SEMBAPALA and surrounding community.

The management of Mount Rinjani National Park had also carried out preventive action as part of hazard management effort, incorporating fire prevention, hazard warning board installation, hiking trail closing, patrol, hiking trail structuring, disaster-prone area map generation, early warning system set-up, Mount Rinjani monitoring, and evacuation route map generation. In addition, the management also provided insurance in cooperation with an insurance company. The cost of insurance was included in the entry ticket fee paid by the visitors. However, low perception of hazard influenced visitors to buy the insurance (Baker, 1993). There were quite a high number of visitors who rejects the idea of purchasing insurance for themselves, thinking that it was not necessary.

Edelweiss Medical Help Center (EMHC), one of Mount Rinjani National Park Office partners, performed the repressive action to save the victim of accidents. The EMHC was a medical team assigned to evacuate and provide medical treatment for the victims of accidents in the Mount Rinjani hiking trail. The team consisted of a doctor and 13 paramedics who worked in Sembalun Community Health Center. The cost of handling the victims was obtained from the insurance provided by Amanah Githa Insurance. The existence of this team made Mount Rinjani the first volcano in Indonesia, having implemented evacuation within clearly-defined safety procedures and organizational structure.

Physical and biological hazards found in the SembalunSenaru hiking trail Mount Rinjani National Park presented varying risk from low to high risk. Therefore, all four management options offered in Wilks and Moore (2004) and UNEP (2008), i.e., avoiding risk, reducing risk, accepting the tolerable risk, and transferring risk, should be applied in the trail. Avoiding risk was suitable for low temperature, fog, and long-tailed macaque hazards. The action to avoid risk should include providing education for the visitors/hikers in the form of announcements and warning board installation for the visitors/hikers to be able to prevent the hazard.

Reducing risk was the option for hazards from the gorge, slippery/steep trail, and tree root. The management may consider installing safety rope, fence, or handrail as necessitating by the trail condition. The management may apply to accept tolerable risk option for risks generated by a landslide, volcanic activity, fire, transverse tree branch, wild boar, and eastern poison ivy hazards. Attempt to provide education for visitors through various means, such as warning boards, maybe a suitable action for this management option.

Transferring risk options is transferring financial risk to other parties, usually the insurance company. The option may be appropriate for bee and wasp hazard in case of severe allergic reaction occurs to the victim of bee/wasp sting. This option can also be applied for other hazards with high financial risk. Providing insurance may help in covering the cost requires for evacuation and medical treatment of the victims. It is an important management strategy to face the uncertainty of future incidents (Cioccio \& Michael, 2007).

The risk of the human activity-induced hazard was 
varying from moderate to critical. Education is vital as a part of the hazard management strategy concerning human activity-induced hazards. In addition, effective enforcement of standard operating procedures or any other hiking-related regulation by carrying out health examination and hiking equipment may help in lowering the risk of human activityinduced hazards. However, a different strategy should be found to overcome the shortcomings of officer quantity to do the checking. Assuming that the control action is applicable, the risks may be lower down from critical to serious, and from moderate to minor (Table 2).

Aside from providing adequate safety equipment in the locations that require the equipment, the management of Mount Rinjani National Park may consider education as an important management strategy. Education should be provided not only for visitors/hikers but also for the community to be able to aid in the hazard management of the area (Meilani et al., 2018). For visitors, education may take the form of interpretation services to improve visitors' capacity on hazard (Meilani et al., 2018; Muthiah et al., 2018). In the Kosciuszko alpine area, interpretation and safety messages are provided in lookout sites (Pickering et al., 2003). Sufficient information, such as a map of the hiking trail with hazard-related information, characteristics of the locations, equipment needed, how to make an emergency call during accidents, provide early education that may help prospective hikers to make better preparation prior hiking. Therefore, such information should be made easily accessible. The digital platforms, such as website or smartphone application, may also provide an option in providing provide such hazard-related information that can be used to improve visitors' capability in overcoming the hazard. Recommendations for Physical and biological hazard management ( Table 3).

\section{Conclusion}

The potential hazards were found in the SembalunSenaru hiking trail, Gunung Rinjani National Park, consisting of physical, biological, and human activities. Potential physical hazards in the Sembalun-Senaru climbing route with the highest level of risk that is a gap with a risk value of 32, and the lowest is a fire with a risk value of 4 . Potential biological hazards with the highest risk level are tree roots with a risk value of 18 , and the lowest is a jelateng with a risk value of 6 . Human activity with the highest risk score (critical) is running, and the lowest risk score (moderate) is fishing. Hazard management that can be done is through preventive measures by increasing public knowledge and visitors to the types and locations of hazards on Mount Rinjani and repressive actions, namely by handling accident events. Recommendations for Physical and biological hazard management

\section{Acknowledgments}

This paper is a part of research entitled 'Tourism Hazard Management in Disaster-Prone Areas in Indonesia. The research was funded by the Ministry of Research, Technology, and Higher Education through Leading Strategic Research Scheme of University Leading Research.

\section{Declaration of Interest Statement}

The manuscript submitted represents original work and has not been previously published or simultaneously submitted elsewhere for publication. All authors have read and approved this manuscript.

Table 3 Recommendations for physical and biological hazard management

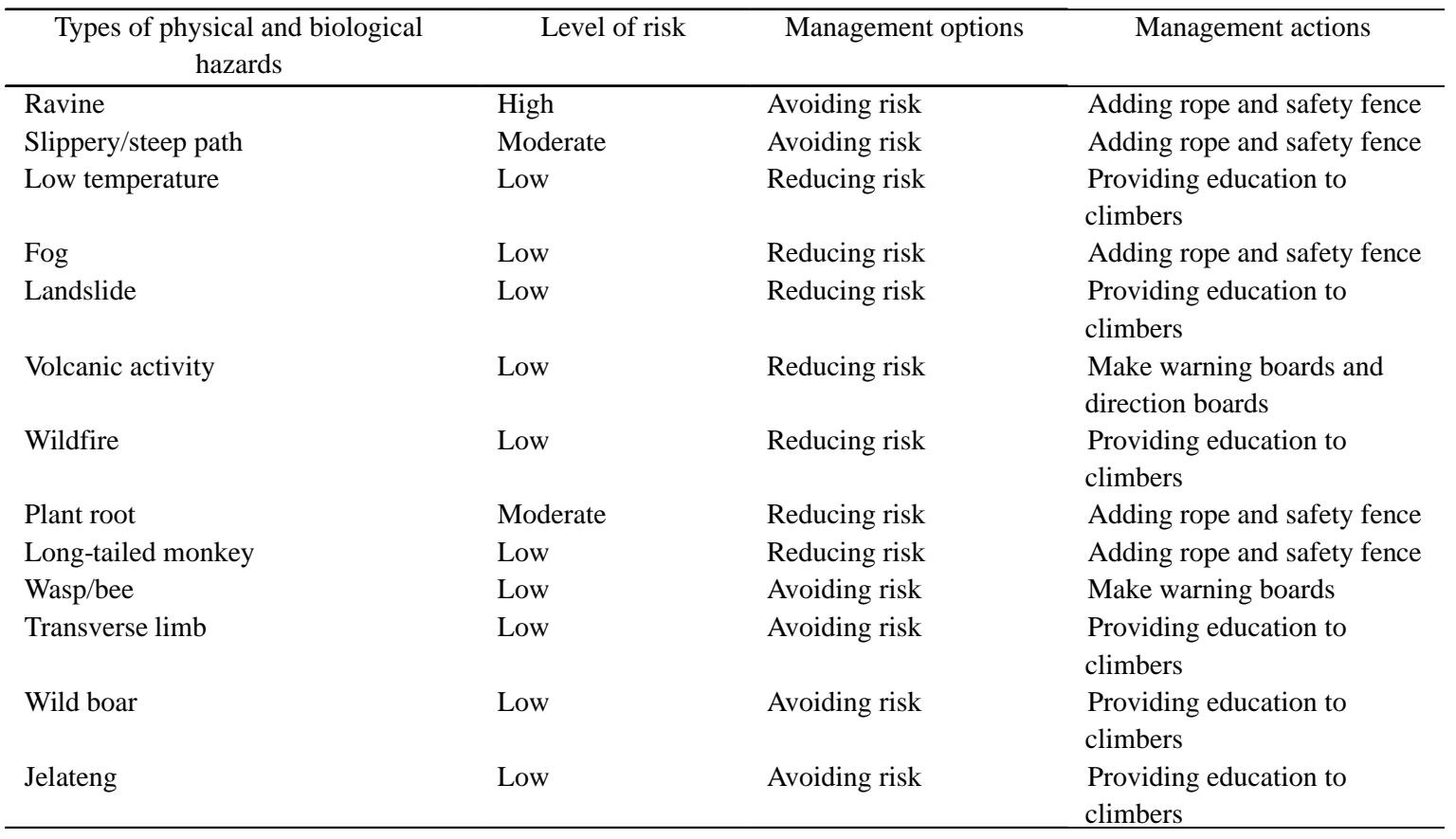




\section{References}

Adinegara, G. N. J., Suprapti, N. W. S., Yasa, N. N. K., \& Sukaatmadja, I. P. G. (2017). Factors that influences tourist's satisfaction and its consequences. European Journal of Business and Management, 9(8), 39-50.

Alexander, D. (2013). All-Hazards. In K. B. Penuel, M. Statler, \& R. Hagen (Eds.), Encyclopedia of Crisis Management (pp. 247-250). New York: SAGE Publications, Inc. https://doi.org/10.4135/97814522759 56.n4

Aliman, N. K., Hashim, S. M., Wahid, S. D. M., \& Harudin, S. (2016). Tourists' satisfaction with a destination: An investigation on visitors to Langkawi Island. British Journal of Marketing Studies, 4(5), 1-20. https://doi.org/10.5539/ijms.v8n3p173

Arnold, J. J., \& Williams, P. M. (2011). Anaphylaxis: recognition and management. American Family Physicians, 84(10), 1111-1118.

Baker, R. G. (1993). Tourism and community perceptions: An examination of Mount St. Helens' Tourism as perceived by local residents. Oregon: Oregon State University.

Balch, J. K., Bradley, B. A., Abatzoglou, J. T., Nagy, R. C., Fusco, E. J., \& Mahood, A. L. (2017). Human-started wildfires expand the fire niche across the United States. Proceedings of the National Academy of Sciences, 114(11), 2946-2951. https://doi.org/10.1073/pnas. 1617394114

Bjønness, I. M. (1986). Mountain hazard perception and riskavoiding strategies among the Sherpas of Khumbu Himal, Nepal. Mountain Research and Development, 6(4), 277-292. https://doi.org/10.2307/3673369

[CDC] Centers for Disease Control and Prevention. (2005). Hypothermia-related deaths -- United States, 2003-2004. Retrieved from https://www.cdc.gov/mmwr/ preview/mmwrhtml/mm5407a4.htm

Cioccio, L., \& Michael, E. J. (2007). Hazard or disaster: Tourism management for the inevitable in Northeast Victoria. Tourism Management, 28(1), 1-11. https://doi.org/10.1016/j.tourman.2005.07.015

Darlington, E. D. (1986). Look out ! It's poison ivy! Science and Children, 24(1), 10-15. Retrieved from https://www.jstor.org/stable/43166264

Erfurt, P. J. (2011). An assessment of the role of natural hot and mineral springs in health, wellness and recreational tourism. Queensland: James Cook University. Retrieved from http://eprints.jcu.edu.au/31110/

Gitapala. (2014). Standar operasional prosedur Divisi Hutan Gunung [Standard operational procedure of Forest Mountain Division]. Retrieved http://www.gitapala.tp. ugm.ac.id/standar-operasional-prosedur-divisi-hutangunung/
Golden, D. B. K. (2003). Stinging insect allergy. American Family Physicians, 67(12), 2541-2546. Retrieved from https://www.aafp.org/afp/2003/0615/p2541.pdf

Gupta, S. P. (2013). Hazard, Definition of. In K. B. Penuel, M. Statler, \& R. Hagen (Eds.), Encyclopedia of Crisis Management (pp. 441-442). New York: SAGE Publications, Inc. https://doi.org/10.4135/9781452 275956.n151

Healthline Editorial, T., \& Jewell, T. (2017). Hot and cold: Extreme temperature safety. Retrieved from https://www.healthline.com/health/extremetemperature-safety\#extreme-cold-temperatures

Helicon. (2018). Fog. In Helicon (Ed.), The Hutchinson unabridged encyclopedia with atlas and weather guide. Abington: Helicon.

Heriyanto, N. M., \& Mukhtar, A. S. (2011). Gangguan satwaliar di lahan pertanian sekitar Taman Nasional Meru Betiri, Jawa Timur. Jurnal Penelitian Hutan Dan Konservasi Alam, 8(1), 55-63. https://doi.org/10.20886/ jphka.2011.8.1.55-63

Jubenville, A., Twight, B. W., \& Becker, R. H. (1987). Outdoor recreation management: Theory and application (Revised an). State College: Venture Publishing, Inc.

Kumpulainen, S. (2006). Vulnerability concepts in hazard and risk assessment. Natural and technological hazards and risks affecting the spatial development of European regions. Geological Survey of Finland, Special Paper 42, $65-74$.

Kurniawan, E. (2004). Panduan mendaki gunung dalam infografis. Jakarta, Indonesia: Tabloid Bola.

Kwak-Hefferan, E. (2007). Hike like a pro. Retrieved from https://search-proquest-com.ezproxy.library.uwa.edu.au/ docview/2030696431 ?accountid=14681.

Kwon, Y. G., \& Park, H. J. (2002). Factor analysis of safety for visitors to a mega-event. International Journal of Occupational Safety and Ergonomics, 8(3), 365-375. https://doi.org/10.1080/10803548.2002.11076536

Leland, J. (2010). Poison ivy. In Learning the valley: Excursions into the Shenandoah Valley (pp. 57-61). United States: Columbia, South Carolina: University of South Carolina Press.

Mardiah, A., Rizaldi, \& Novarino, W. (2015). Agresi provokasi dan non-provokasi pada Monyet Ekor Panjang (Macaca fascicularis, Raffles 1821) terhadap pengunjung di Kawasan Gunung Meru. Jurnal Biologi Universitas Andalas, 4(4), 258-263. https://doi.org/10.25077/jbioua. 4.4.258-263.2015

Meilani, R., Muthiah, J., \& Muntasib, E. K. S. H. (2018). Reducing the risk of potential hazard in tourist activities 
of Mount Bromo. IOP Conference Series: Earth and Environmental Science, 149, 012021. https://doi.org/10. 1088/1755-1315/149/1/012021

Muthiah, J., Muntasib, E. K. S. H., \& Meilani, R. (2018). Tourism hazard potentials in Mount Merapi: how to deal with the risk. IOP Conference Series: Earth and Environmental Science, 149, 012020. https://doi.org/10. 1088/1755-1315/149/1/012020

Naude, M. (n.d.). There \& back safely: Hiking safety considerations, information and protocol. Bridgetown: Cape Nature.

[NPSA] National Patient Safety Agency. (2008). A risk matrix for risk managers. London: The National Patient Safety Agency. https://doi.org/10.1149/1.1342180

[OSHA] Occupational Safety and Health Administration. (2002). Job hazard analysis (Revised ed, Vol. 2002). Washington DC: U.S. Department of Labor Occupational Safety and Health Administration (OSHA).

Palmer, C. (2002). 'Shit happens': The selling of risk in extreme sport. The Australian Journal of Anthropology, 13(3), 323-336. https://doi.org/10.1111/j.18359310.2002.tb00213.x

Pickering, C. M., Harrington, J., \& Worboys, G. (2003). Environmental impacts of tourism on the Australian Alps Protected Areas, Judgments of Protected Area Managers. Mountain Research and Development, 23(3), 247-254. https://doi.org/10.1659/0276-4741(2003)023[0247: EIOTOT]2.0.CO;2

Pigram, J. (1983). Outdoor recreation and resource management. New York: St. Martin's Press, Inc.

Pradhany, R. C., Widyastuti, S. K., \& Wandia, I. N. (2016). Aktivitas harian monyet ekor panjang (Macaca fascicularis) yang telah divasektomi di Wenara Wana Ubud. Indonesia Medicus Veterinus, 5(3), 240-247.

[PVMBG] Pusat Vulkanologi dan Mitigasi Bencana Geologi. 2014. Gunung Rinjani. [Internet]. [Downloaded: 29 Jan 18]. Retrived from: http://www.vsi. esdm.go.id/index.php/gunungapi/data-dasargunungapi/473-g-rinjani.

Saputra, K. G. W., Watiniasih, N. L., \& Ginantra, I. K. (2014). Aktivitas harian kera ekor panjang (Macaca fascicularis) di Taman Wisata Alam Sangeh, Kabupaten Badung, Bali Jurnal Biologi, 18(1), 14-18.

Schwartz, L. (1941). A protective ointment against Ivy poisoning. The American Journal of Nursing, 41(6), 675-678. https://doi.org/10.1097/00000446-194106 000-00011

Soputan, G. E. M., Sompie, B. F., \& Mandagi, R. J. M.
(2014). Manajemen resiko kesehatan dan keselamatan kerja (K3) (Studi kasus pada pembangunan gedung SMA Eben Haezar). Jurnal Ilmiah Media Engineering, 4(4), 229-238.

Suharto. (2016). Studi tentang keamanan dan keselamatan pengunjung hubungannya dengan citra destinasi (Studi kasus Gembira Loka Zoo). Jurnal Media Wisata, 14(1), 287-304. https://doi.org/10.36276/mws.v14i1.149

Sukarmin, Y. (1995). Persiapan fisik bagi pendaki gunung: Sebuah alternatif pencegahan kecelakaan. Cakrawala Pendidikan, 1,91-102.

Sukthana, Y., Lekkla, A., Sutthikornchai, C., Wanapongse, P., Vejjajiva, A., \& Bovornkitti, S. (2005). Spa, springs and safety. Southeast Asian J Trop Med Public Health, 36(suppl 4), 10-16.

Sumann, G., Hochholzer, T., Faulhaber, M., \& Burtscher, M. (2015). High-altitude mountaineering made safer. Trauma, 17(1), 4-16. https://doi.org/10.1177/1460 408614531878

[UNEP] United Nations Environment Programme. (2008). Disaster risk management for coastal tourism destinations responding to climate change: A practical guide for decision makers. Paris \& Santo Domingo: United Nations Environment Programme (UNEP) and Caribbean Alliance for Sustainable Tourism (CAST).

[UNISDR] United Nations Office for Disaster Risk Reduction. (2004). Living with risk: A global review of disaster reduction initiatives (Vol. 1). New York and Geneva: UNISDR. Retrieved from http://www.unisdr. org/files/657_lwr1.pdf

[UNISDR] United Nations Office for Disaster Risk Reduction. (2015). Sendai framework for disaster reduction 2015-2030. Geneva: UNISDR. Retrieved from http://www.unisdr.org/files/43291_sendaiframeworkfor drren.pdf

Vernillo, G., Giandolini, M., Edwards, W. B., Morin, J.-B., Samozino, P., Horvais, N., \& Millet, G. Y. (2017). Biomechanics and physiology of uphill and downhill running. Sports Medicine, 47(4), 615-629. https://doi.org/10.1007/s40279-016-0605-y

Wardana, R.A., Kahar, S., \& Suprayogi, A. (2015). Penyajian peta jalur pendakian Gunung Rinjani berbasis platform android. Jurnal Geodesi Undip, 4(2), 94-100.

Wilks, J., \& Moore, S. (2004). Tourism risk management for the Asia-Pacific Region: An authoritative guide for managing crises and disasters. Gold Coast MC QLD: CRC for Sustainable Tourism Pty Ltd. Retrieved from http://www.aerohabitat.eu/uploads/media/25-01-2005__Tourism_Risk_Management_in_Asia_Pacific_1MB_ .pdf 